\title{
Ultrastructural Clarification of the Peripherally Located Actin Network in the Myelinated Axons
}

\author{
Aclaración Ultraestructural de la Red de Actina Localizada \\ Periféricamente en los Axones Mielinizados
}

\author{
Yue Gui ${ }^{1}$; Shuang Wu${ }^{1}$; Bai-Hong Tan²; Tian-Qing Xiong ${ }^{1} \&$ Yan-Chao Li $^{1}$
}

GUI, Y.; WU, S.; TAN, B. H.; XIONG, T. Q. \& LI, Y. C. Ultrastructural clarification of the peripherally located actin network in the myelinated axons. Int. J. Morphol., 39(1):179-185, 2021.

SUMMARY: Despite the existence of a large amount of actin in the axons, the concentration F-actin was quite low in the myelinated axons and almost all the F-actin were located in the peripheries of the myelinated axons. Until now, the ultrastructural localization of F-actin has still not been reported in the myelinated axons, probably due to the lack of an appropriate detection method. In the present study, a phalloidin-based FITC-anti-FITC technique was adopted to investigate the subcellular localization of F-actin in the myelinated axons. By using this technique, F-actin is located in the outer and inner collars of myelinated cytoplasm surrounding the intermodal axon, the Schmidt-Lanterman incisures, the paranodal terminal loops and the nodal microvilli. In addition, the satellite cell envelope, which encapsulates the axonal initial segment of the peripheral sensory neuron, was also demonstrated as an F-actin-enriched structure. This study provided a hitherto unreported ultrastructural view of the F-actin in the myelinated axons, which may assist in understanding the unique organization of axonal actin cytoskeleton.

KEY WORDS: Axon; F-actin; Electron microscopy; Myelin sheath; Rat.

\section{INTRODUCTION}

Like other cell types, actin within nerve cells is composed of both monomeric (G-actin) and filamentous forms (F-actin), which are dynamically exchanged each other and involved in almost all biological processes (Fifková, 1985; Dillon \& Goda, 2005).

Myelinated spinal nerves are derived from the cell bodies located in spinal ventral horn or in dorsal ganglions (DRGs), beginning with an unmyelinated part called the initial segment (Peters et al., 1991). A variety of experimental data argue strongly for the existence of a large amount of actin in the axons (Morris \& Lasek, 1984; Tsukita et al., 1986; Fath \& Lasek, 1988). In adult myelinated axons, immunostaining against actin showed that actin positive signals were present throughout the axoplasm (Goldman, 1983), but phalloidin fluorescence analysis showed that myelinated axons contain a little F-actin which was present mainly in the peripheries of the myelinated axons (Drenckhahn et al., 1984).
In contrast to the almost negligible staining within the axoplasm, the peripherally located fluorescence for Factin in the myelinated axons has attracted more attention of researchers. Interestingly, such a typical fluorescent pattern is observed only in the myelinated portion, but not in the axonal initial segment, suggesting that the F-actinenriched structures may be located outside the axons (Zimmermann, 1996). However, until now the ultrastructural localization of F-actin has still not been reported in the myelinated axons.

It is well known that ultrastructural detection of Factin is not easily achieved because F-actin is apt to depolymerize following fixation and dehydration (Small, 1981; Hirokawa, 1982). In addition, both G- and F-actin are present in the nerve cells (Micheva et al., 1998; Dillon \& Goda), which cannot be distinguished only by using antiactin immunochemistry.

\footnotetext{
${ }^{1}$ Department of Histology and Embryology, College of Basic Medical Sciences, Norman Bethune Health Science Center of Jilin University, Changchun, Jilin Province, 130021, P.R. China.

${ }^{2}$ Laboratory Teaching Center of Basic Medicine, College of Basic Medical Sciences, Norman Bethune Health Science Center of Jilin University, Changchun, Jilin Province, 130021, P.R. China.
} 
We have previously developed an ultrastructual detection method of F-actin by use of a FITC-specific antibody and a highly probe specific for F-actin, phalloidin (Li et al., 2009, 2010; Tan et al., 2017). In the present study, this technique was used to investigate the subcellular distribution of F-actin within the myelinated axons.

\section{MATERIAL AND METHOD}

\section{Experimental Procedure}

Antibodies and Animals. FITC-binding phalloidin (P5282) and biotin-conjugated antibody against FITC (Clone FL-d6; Sigma) were obtained from Sigma (St. Louis, MO). This study used 5 adult SD rats (female $380-420 \mathrm{~g}$ ), which was approved by the Animal Research Committee of Jilin University, and handled in accordance with the NIH Guide for the Care and Use of Laboratory Animals.

Phalloidin staining and electron microscopy. The animals were perfused, and processed as described previously by us (Li et al., 2009). Spinal cords, DRGs, and spinal nerves were dissected out at the level of L4 L5, and cut into sections about $50 \mathrm{~mm}$ thick by a vibratome. The sections were then stained with FITC-conjugated phalloidin, which were further converted to peroxidase/DAB products by a FITC-anti-FITC system (Li et al., 2009).

Light and ultrastructural observations. The phalloidin stained sections were examined with a laser scanning confocal microscope (Olympus FV1000), as described previously by us (Li et al., 2009). The DAB stained sections were photographed using an Olympus BX53F microscope equipped with a digital imaging system (Olympus, Tokyo, Japan). Ultrathin sections were examined and photographed with a transmission electron microscope (JEOL JEM 1200EXII).

\section{RESULTS}

The location of $\mathrm{F}$-actin revealed by phalloidin staining and confocal microscopy. In the spinal cord (Fig. 1A), FITCphalloidin staining was found mainly in the peripheries of nerve cells. The neuronal somata remained unstained, except for weak fluorescence scattered in the perikaryal cytoplasm. The bulk cytoplasm remained unstained, but the outer peripheries displayed strong fluorescence signals (Fig. 1A). Blood vessels were intensely stained, which could be identified by their hollow circular appearance. However, it was unclear whether these positive structures were located in the nerve cells or not even at higher magnification. Moreover, axon hillock and initial segment could not be distinguished under the fluorescence microscope.

In the DRG (Fig. 1C), the axonal initial segments of the sensory neurons were easily identified near the neuronal cell bodies (Fig. 1C). The cytoplasm of neuronal somata and the axoplasm were devoid of fluorescence, but the peripheries surrounding the neuronal somata and axons were brightly labeled. Because the neurons and the satellite cells were in close apposition, analysis of the fluorescence microscopic images could not determine the precise localization of F-actin in the DRG axons.

In spinal nerves (Fig. 1E), the outer and inner perimeters of myelinated fibers were moderately stained, but the intermodal axoplasm was virtually devoid of fluorescence. In the longitudinal sections, the Schmidt-Lanterman incisures, identified by "arrowhead" appearances, were intensely labeled (arrowheads in Fig. 1E). The paranodal and nodal regions were prominently stained. A strongly labeled central band could be discerned in the nodal region (arrows in Fig. 1E). By contrast, the paranodal labeling seemed a little weaker and thinner, and was not continuous with the central band in the nodal region.

Electron microscopic localization of F-actin. By using a phalloidin-based anti-FITC method, we changed the fluorescence signals revealed by phallodin to peroxidase/DAB reaction products, which can be detected under both light and electron microscopes (Figs. 1B, 1D and 1F). The specificity of this technique has previously been reported (Li et al., 2009, 2010; Tan et al.), and was further confirmed in this study by replacing phalloidin or the secondary antibody with phosphate buffer.

Electron microscopic detection of the DAB deposited samples showed that F-actin was localized predominately in the surrounding regions around the neuronal cell bodies and dendrites in the spinal cord (Fig. 2A). At higher magnification, almost all the positive sites were found as terminal boutons. The axon hillock was similarly covered with positively labeled axonal terminals, but rare staining was found around the initial segment, where no axon terminals are present (Figs. 2A and 2B). The cytoplasm of neuronal cell bodies and their processes remained unstained, but diffuse staining was often seen surrounding membranous organelles.

Different from the spinal cord, no synapses are present in the DRGs. The cell bodies and the axon initial segments of DRG neurons were surrounded by a unique glial envelope formed by satellite cells. The bulk cytoplasm of the DRG neurons remained unstained or very faintly stained (Figs. 

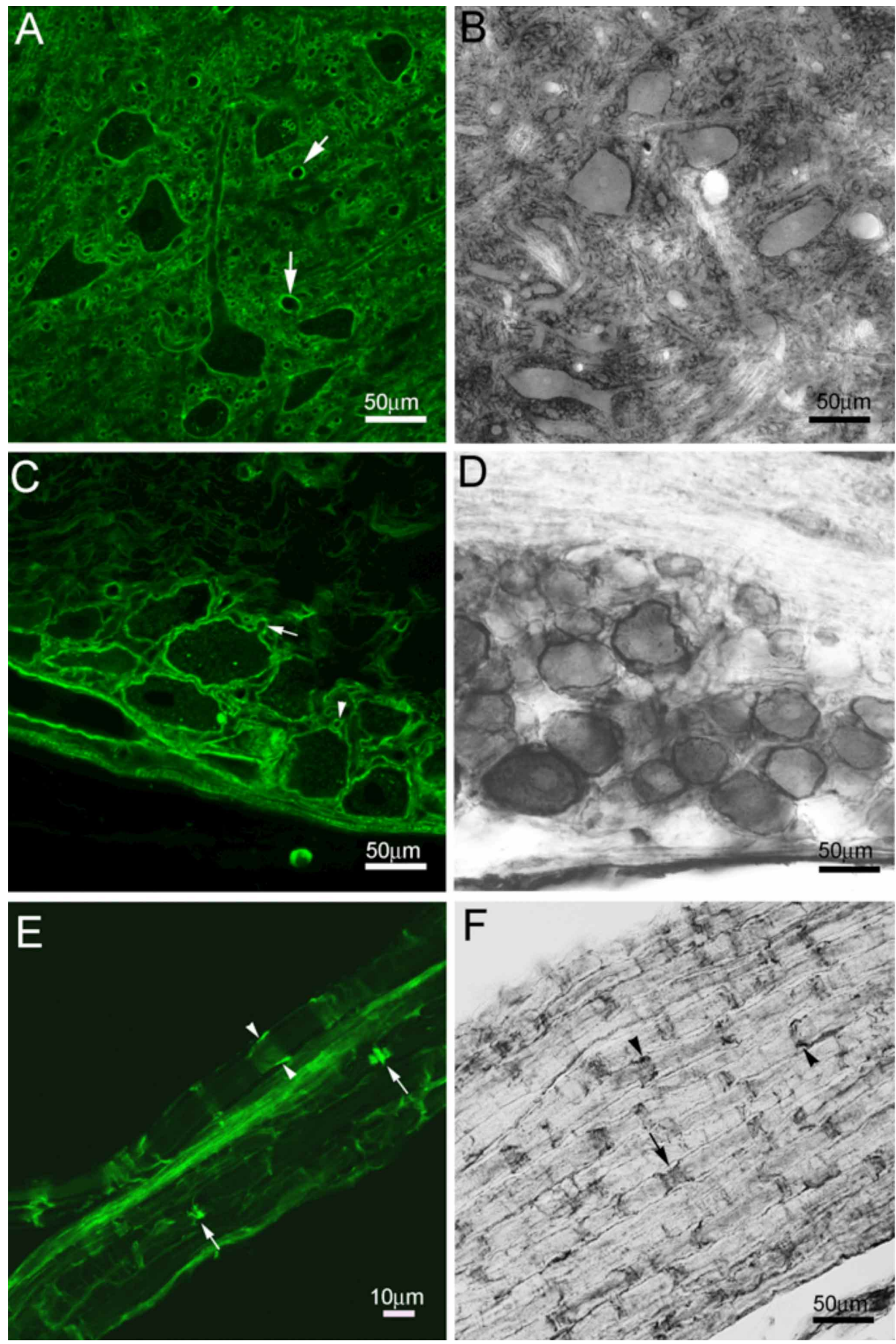

Fig. 1. Fluorescence (left) and light (right) microscopic images showing the distribution of F-actin. A - B: In the ventral horn of spinal cord, FITCconjugated phalloidin staining reveals ring-like structures surrounding the neuronal somata and their processes (A). The cytoplasm is virtually unstained. Blood vessels of various sizes in the gray matter are strongly labeled (arrows in A). The fluorescence signals for F-actin are converted to peroxidase/DAB reaction products (B) by the FITCanti-FITC-system. Consistent with the fluorescence signals, the positive products for F-actin are localized predominantly in the peripheries of the cell bodies and the processes (B). C - D: In the DRG, phalloidin staining shows that the outer boundaries of the DRG neurons are intensely labeled (C).The ring-like positive structures are also found around the axon initial segments (arrows in C). Conversion from fluorescence signals to peroxidase/DAB reaction products shows that the positive products are localized in the peripheral regions of the DRG neurons (D). E - F: In the longitudinally cut spinal nerves, phalloidin staining shows that the nodes of Ranvier (arrows) and the Schmidt-Lanterman incisures (arrowheads) are intensely labeled (E). Weak staining is also present in the outer periphery of the myelin sheath and at the interface between the myelin sheath and the subjacent axon. The intermodal axoplasm is unstained, or very faintly stained. Conversion from fluorescence signals to peroxidase/DAB reaction products obtains similar results (F). Arrow in F: Nodes of Ranvier; arrowheads in F: Schmidt-Lanterman incisures.
2C and 2D). The positive products for F-actin were concentrated mainly in the satellite cell lamellae, around the cell bodies as well as in the adaxonal region of the satellite cell envelope. In addition, weak staining was also found sparsely beneath the plasma membrane.

In the myelinated nerves, the outer margin of compact myelin and the adaxonal cytoplasm of the myelin-forming cells were intensely labeled, appearing as a double train track pattern around the intermodal axon (Figs. 3A and 3B). At higher magnification, it was clear that the positive products for Factin were concentrated in the outer and inner collar cytoplasm of Schwann cells (Fig. 3C) or oligodendrocytes (Fig. 3B). The subjacent axons were very faintly stained, and only diffuse staining was found in the axoplasm, often associated with membranous organelles such as mitochondria. 

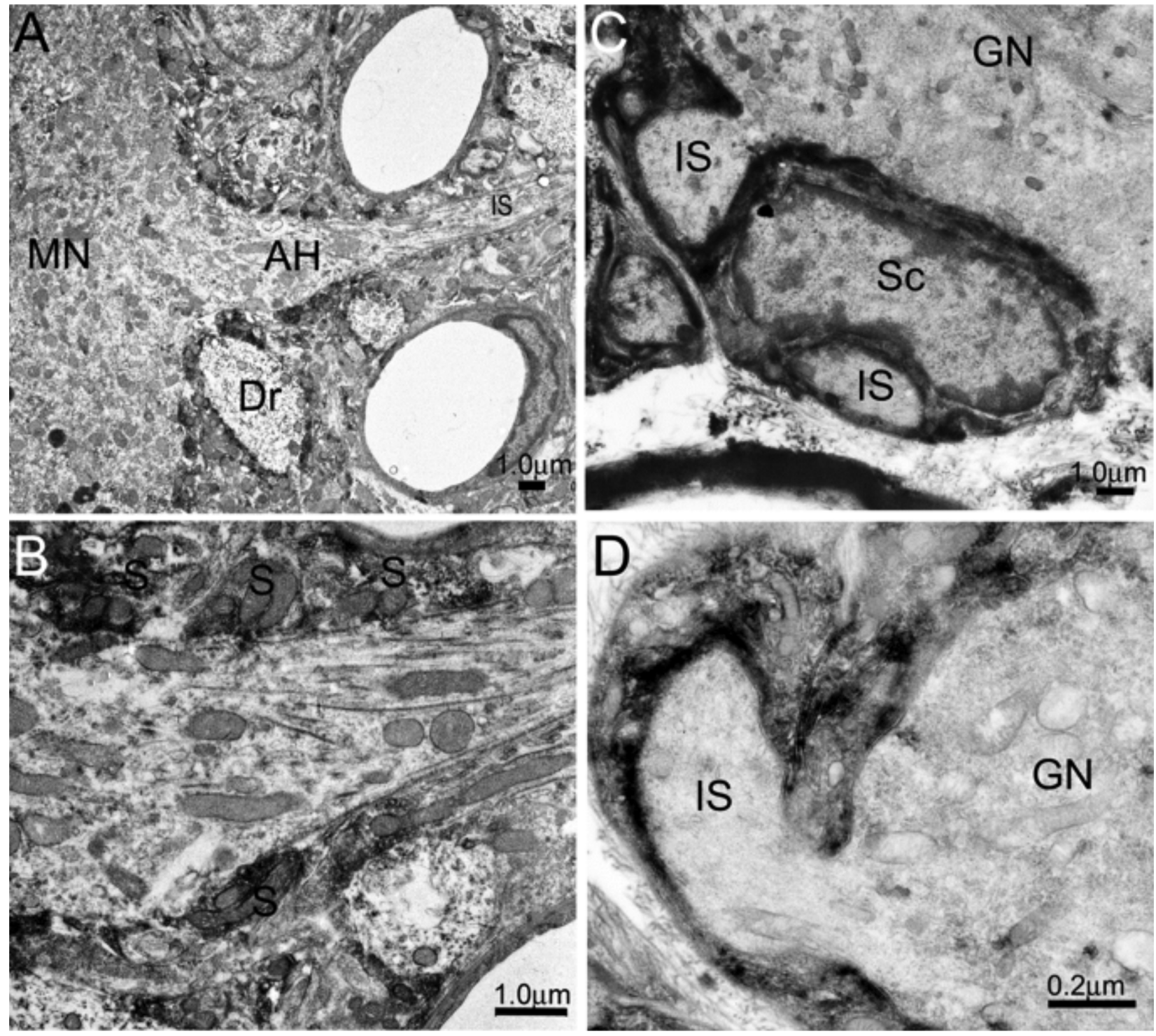

Fig. 2. Ultrastructural localization of F-actin in the axon initial segments. In the spinal motoneurons (MN, in A), the positive products for F-actin are localized predominantly in the peripheral regions along the outer boundaries of the cell bodies and their processes. The axon hillock (AH, enlarged in B) is covered with positively stained axonal terminals. No positive labeling is seen in the initial segment (IS), where no axon terminals are present around the axon. Several transversely cut dendrites can be observed (Dr), which are also touched by positively stained axonal terminals. In the DRG (C and D), the positive products for F-actin are located in the adaxonal region of the satellite cell (SC) envelope around the axon initial segment (IS). Less intensely stained materials are seen sparsely beneath the plasma membrane of the axon or the DRG neuron $(\mathrm{GN})$, but the bulk cytoplasm remains unlabeled.

As observed under the confocal microscope, the Schmidt-Lanterman incisures and nodal regions were demonstrated as the major F-actin-rich components. In the Schmidt-Lanterman incisures, the peroxidase/DAB reaction products were localized in the cytoplasmic channels of Schwann cells (Fig. 3D), and the surrounding membrane was also densely deposited with the positive products. In the nodal region, the Schwann cell microvilli and paranodal terminal loops are intensely labeled (Fig. 3D). The nodal axon, which is covered by Schwann cell microvilli, was found to contain a dense and continuous $\mathrm{F}$-actin layer beneath the axoplama membrane (insets in Figs. 3E and 3F).

The labeling for F-actin was very specific, insofar as no positive reaction could be detected in the negative controls (Fig. 4). 

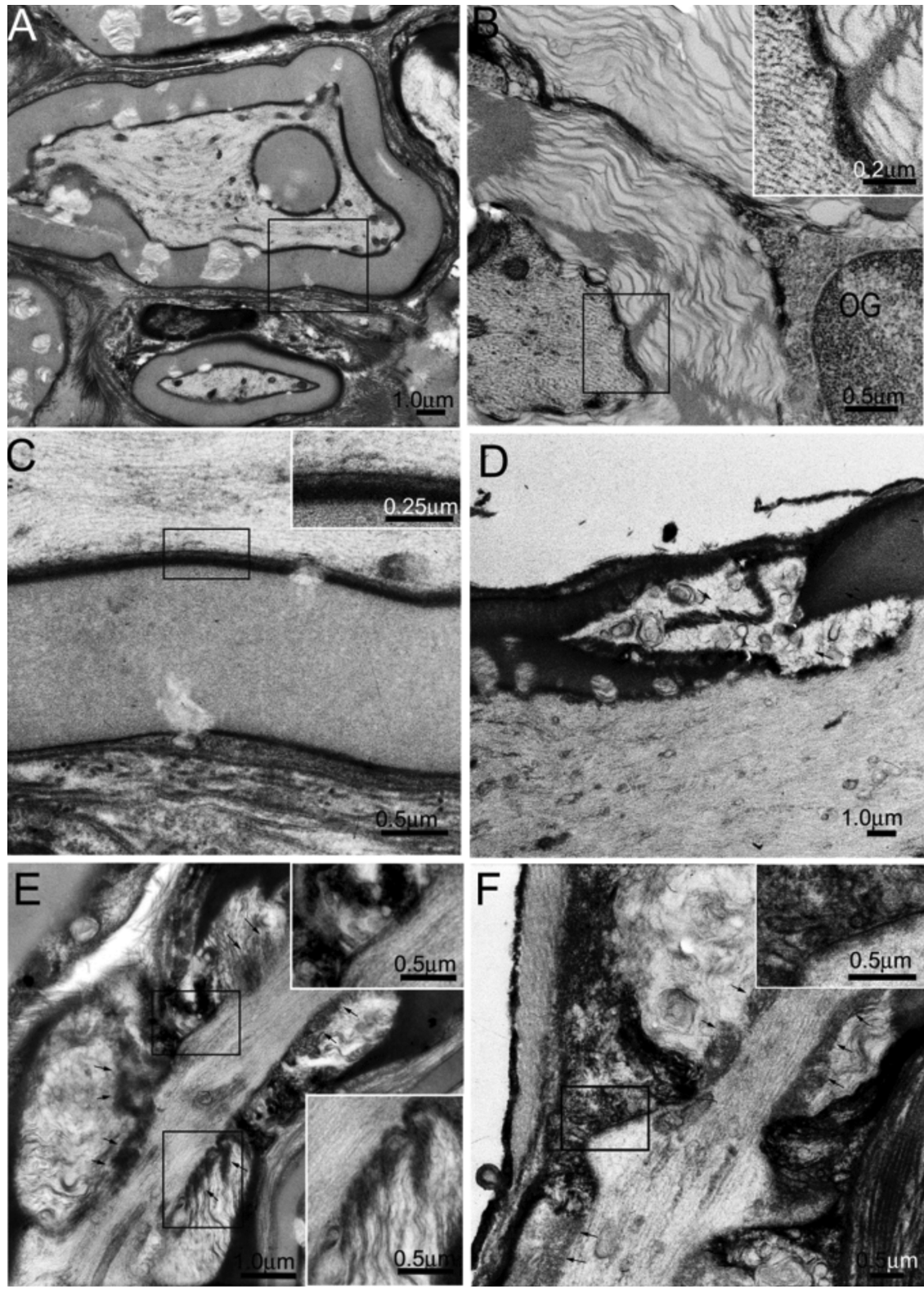

Fig. 3 Ultrastructural localization of F-actin in the myelinated axons. Image A shows two transversely-cut lumber nerve fibers. The outer margin of compact myelin and the adaxonal Schwann cell cytoplasm are intensely labeled, appearing as a double train track pattern around the intermodal axon. The rectangled area in A is enlarged in C. At the higher magnification, it is clear that the positive products for F-actin are concentrated in the outer and inner collars of Schwann cell cytoplasm. The boxed area in $\mathrm{C}$ is further enlarged in the up-right inset. Within the subjacent axon, less intensely stained materials are observed in the cortical regions. The axoplasm is virtually unstained, but diffuse staining is found throughout the axoplasm. Image B shows a myelinated axon in the white matter of spinal cord. Both the outer and inner collars of oligiodendritic cytoplasm are intensely deposited with the positive products (see the inset for details). The positively labeled outer collar is seen continuous with the cell body of an oligodendrocyte (OG). In the Schmidt-Lantermanincisure of the lumber nerve fiber (D), the positive products for $\mathrm{F}$ actin are localized in the cytoplasmic channels of Schwann cell. The surrounding membranous structures are also deposited with the positive reaction products. In the node of Ranvier of lumber nerve fibers (E and F), the Schwann cell microvilli are strongly labeled. The nodal regions in $\mathrm{E}$ and $F$ are partially enlarged in the up-right insets in $\mathrm{E}$, and $\mathrm{F}$, respectively, where an F-actinpositive layer is observed beneath the axolemma. Less intense staining is also observed in the paranodal terminal loops (arrows). The paranodalteminal loops in $\mathrm{E}$ is further enlarged in the low-right inset.

\section{DISCUSSION}

In the present study, the F-actin positive signals revealed by phalloidin in the spinal cord, DRG and myelinated axons have been converted to the peroxidase/DAB products by a specific FITC-anti-FITC system, described previously by us (Li et al., 2009). This technique demonstrated that Factin was located in the outer and inner collars of myelin cell cytoplasm surrounding the intermodal axon, the SchmidtLanterman incisures, the paranodal terminal loops and the nodal microvilli. In addition, the satellite cell envelopes, which encapsulate the axonal initial segment of DRG neurons, were also demonstrated as the F-actin-enriched structure. The myelinated axons in the CNS share many common morphological features with their counterparts in the PNS (Arroyo \& Scherer, 2000). Similarly, the positive products for F-actin in the CNS were also localized outside the axon, mainly in the inner and outer collars of oligodendritic cytoplasm. In the CNS we also found that $\mathrm{F}$-actin is present within the axonal terminals forming synaptic junctions on the neuronal cell bodies and on the dendrites (Li et al., 2010). However, almost no positive products for $\mathrm{F}$-actin were detected in the axonal 

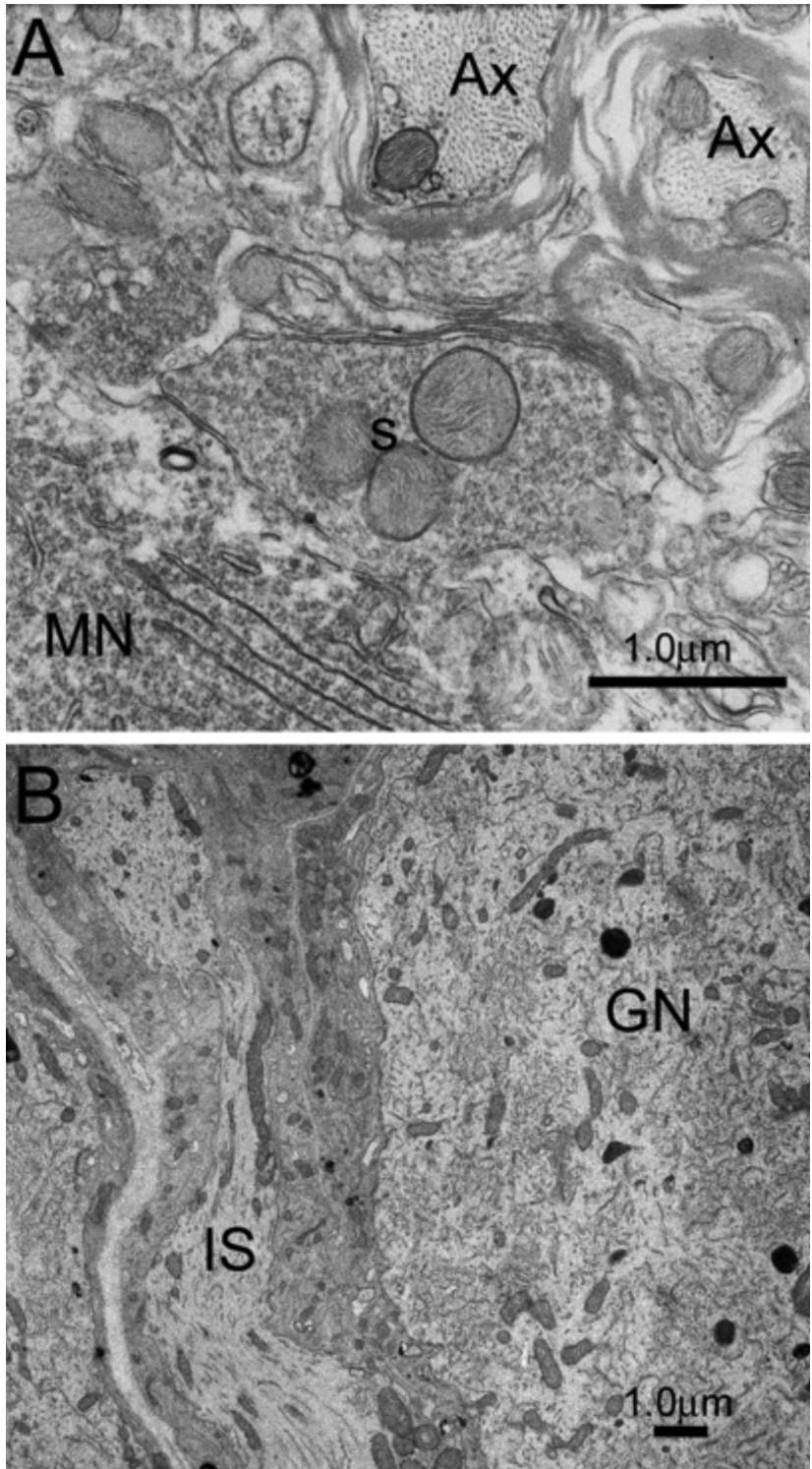

Fig. 4 Electron microphotographs from the controls. A: No positive staining is seen in the axonal terminals $(\mathrm{S})$ around the neuronal soma of a spinal motoneuron (MN). Two unstained myelinated axons (Ax) can be seen in the neuropils. B: No positive staining is seen around the cell body of a DRG neuron $(\mathrm{GN})$ or around the initial segment (IS).

initial segment of spinal motoneurons, consistent with the fluorescence data reported previously (Zimmermann). Although we did not encounter the incisures and the nodal regions of central myelinated axons, the results together indicated that the fluorescence signals revealed by phalloidin in the myelinated axons are mainly extra-axonal in the myelin-forming cells.

F-actin is well known to play a crucial role in the maintenance of cell shape and adhesion (Fifková; Dillon \&
Goda), therefore the highly organized F-actin networks described here may be one way of imposing rigidity and compartmentalization to maintain the unique myelin-axonal connections. In support of this, the localization of F-actin in the non-compact myelin and in the inner and outer collars of glial cytoplasm coincides with the presence of numerous adherens junctions in these regions in the myelinated axon (Fannon et al., 1995). Similarly, junctional complexes also exist between the satellite cell lamellae within the same envelope in the DRGs (Pannese, 1981).

The adherens junctions contain E-cadherin, a $\mathrm{Ca}^{2+}$ dependant cell adhesion molecule, whose cytoplasmic domain is linked to F-actin by alpha-catenin and beta-catenin (Fannon et al.). The inner surface of myelinated cells is highly enriched in myelin-associated glycoprotein (Yang et al., 1996; Trapp et al., 1989a,b), which is an actin-associated integral membrane glycoprotein. This glycoprotein is also present in the apposing plasma membranes in the Schmidt-Lanterman incisures and the paranodal loops of myelinating Schwann cells (Tapp et al., 1989b). In addition, an intrinsic membrane glycoprotein called Caspr has been demonstrated in the paranodal axolemma of myelinated fibers in both the CNS and PNS (Einheber et al., 1997; Menegoz et al., 1997). The cytoplasmic domain of Caspr possesses a binding site for protein 4.1, by which Caspr is linked to F-actin (Arroyo \& Scherer). These actin-associated proteins found in the myelinated axons indicate a potential linkage of F-actin with the plasma membrane.

On the other hand, since F-actin has a dual role as a structural and contractile protein in the eukaryotic cells (Fifková; Dillon \& Goda; Robertson et al., 2009), the F-actin network described here should not be considered only as a supportive structure. Immunostaining studies showed that myosin, the force-generating counterpart of actin, is also present in the nodal and paranodal regions, as well as in the periphery of the intermodal axon (Zimmermann \& Vogt, 1989). The colocalization of myosin and F-actin is suggestive of a contractile role for F-actin in these regions (Zimmermann \& Vogt; Zimmermann).

Taken together, the present study provided a hitherto unreported ultrastructural view of the subcellular distribution of F-actin, which may assist in understanding the unique organization of actin cytoskeleton in the myelinated axons.

\section{ACKNOWLEDGEMENTS.}

Grant sponsor: National Natural Science Foundation of China (General Program) Grant number: No. 81871014 (to $\mathrm{YC} \mathrm{Li}$ ) 
GUI, Y.; WU, S.; TAN, B. H.; XIONG, T. Q. \& LI, Y. C. Aclaración ultraestructural de la red de actina localizada periféricamente en los axones mielinizada. Int. J. Morphol., 39(1):179-185, 2021.

RESUMEN: A pesar de la existencia de una gran cantidad de actina en los axones, la concentración de F-actina era bastante baja en los axones mielinizados y casi la totalidad de F-actina se localizaba en las periferias de los axones mielinizados. A la fecha aún no se ha reportado la localización ultraestructural de F-actina en los axones mielinizados, probablemente debido a la falta de un método de detección apropiado. En el presente estudio, se adoptó una técnica FITC-anti-FITC basada en faloidina para investigar la localización subcelular de F-actina en los axones mielinizados. Mediante el uso de esta técnica, la F-actina se localiza en los collares externo e interno del citoplasma mielinizado que rodea el axón intermodal, a las incisiones de Schmidt-Lanterman,a las asas terminales paranodales y a las microvellosidades nodales. Además, la envoltura de la célula satélite, que encapsula el segmento axonal inicial de la neurona sensorial periférica, también se demostró como una estructura enriquecida con F-actina. Este estudio proporcionó una vista ultraestructural de la F-actina en los axones mielinizados, que puede ayudar a comprender la organización única del citoesqueleto de actina axonal.

PALABRAS CLAVE: Axon; F-actina; Microscopio de electrones; Vaina de mielina; Rata.

\section{REFERENCES}

Arroyo, E. J. \& Scherer, S. S. On the molecular architecture of myelinated fibers. Histochem. Cell Biol., 113(1):1-18, 2000.

Dillon, C. \& Goda, Y. The actin cytoskeleton: integrating form and function at the synapse. Аnпи. Rev. Neurosci., 28:25-55, 2005.

Drenckhahn, D.; Frotscher, M. \& Kaiser, H. W. Concentration of F-actin in synaptic formations of the hippocampus as visualized by staining with fluorescent phalloidin. Brain Res., 300(2):381-4, 1984.

Einheber, S.; Zanazzi, G.; Ching, W.; Scherer, S.; Milner, T. A.; Peles, E. \& Salzer, J. L. The axonal membrane protein Caspr, a homologue of neurexin IV, is a component of the septate-like paranodal junctions that assemble during myelination. J. Cell Biol., 139(6):1495-506, 1997.

Fannon, A. M.; Sherman, D. L.; Ilyina-Gragerova, G.; Brophy, P. J.; Friedrich Jr., V. L. \& Colman, D. R. Novel E-cadherin-mediated adhesion in peripheral nerve: Schwann cell architecture is stabilized by autotypic adherens junctions. J. Cell Biol., 129(1):189-202, 1995.

Fath, K. R. \& Lasek, R. J. Two classes of actin microfilaments are associated with the inner cytoskeleton of axons. J. Cell Biol., 107(2):613-21, 1988.

Fifková, E. Actin in the nervous system. Brain Res., 9(2):187-215, 1985.

Goldman, J. E. Immunocytochemical studies of actin localization in the central nervous system. J. Neurosci., 3(10):1952-62, 1983.

Hirokawa, N. Cross-linker system between neurofilaments, microtubules, and membranous organelles in frog axons revealed by the quick-freeze, deep-etching method. J. Cell Biol., 94(1):129-42, 1982.

Li, Y. C.; Bai, W. Z.; Sakai, K. \& Hashikawa, T. Fluorescence and electron microscopic localization of F-actin in the ependymocytes. J. Histochem. Cytochem., 57(8):741-51, 2009.

Li, Y. C.; Bai, W. Z.; Zhou, L.; Sun, L. K. \& Hashikawa, T. Nonhomogeneous distribution of filamentous actin in the presynaptic terminals on the spinal motoneurons. J. Comp. Neurol., 518(16):3184-92, 2010.

Menegoz, M.; Gaspar, P.; Le Bert, M.; Galvez, T.; Burgaya, F.; Palfrey, C.;
Ezan, P.; Arnos, F. \& Girault, J. A. Paranodin, a glycoprotein of neuronal paranodal membranes. Neuron, 19(2):319-31, 1997.

Micheva, K. D.; Vallée, A.; Beaulieu, C.; Herman, I. M. \& Leclerc, N. beta-Actin is confined to structures having high capacity of remodelling in developing and adult rat cerebellum. Eur. J. Neurosci., 10(12):378598, 1998.

Morris, J. R. \& Lasek, R. J. Monomer-polymer equilibria in the axon: direct measurement of tubulin and actin as polymer and monomer in axoplasm. J. Cell Biol., 98(6):2064-76, 1984.

Pannese, E. The satellite cells of the sensory ganglia. Adv. Anat. Embryol. Cell Biol., 65:1-111, 1981.

Peters, A.; Palay, S. L. \& Webster, H. The Fine Structure of the Nervous System: Neurons and Their Supporting Cells. 3rd ed. Oxford, Oxford University Press, 1991. pp.101-234.

Robertson, A. S.; Smythe, E. \& Ayscough, K. R. Functions of actin in endocytosis. Cell. Mol. Life Sci., 66( 13):2049-65, 2009.

Small, J. V. Organization of actin in the leading edge of cultured cells: influence of osmium tetroxide and dehydration on the ultrastructure of actin meshworks. J. Cell Biol., 91(3 Pt. 1):695-705, 1981.

Tan, B. H.; Guo, C. Y.; Xiong, T. Q.; Chen, L. M. \& Li, Y. C. The unique organization of filamentous actin in the medullary canal of the medulla oblongata. Tissue Cell, 49 (2 Part. B):336-44, 2017.

Trapp, B. D.; Andrews, S. B.; Cootauco, C. \& Quarles, R. The myelinassociated glycoprotein is enriched in multivesicular bodies and periaxonal membranes of actively myelinating oligodendrocytes. $J$. Cell Biol., 109(5):2417-26, 1989a.

Trapp, B. D.; Andrews, S. B.; Wong, A.; O'Connell, M. \& Griffin, J. W. Co-localization of the myelin-associated glycoprotein and the microfilament components, F-actin and spectrin, in Schwann cells of myelinated nerve fibres. J. Neurocytol., 18(1):47-60, 1989b.

Tsukita, S.; Tsukita, S.; Kobayashi, T. \& Matsumoto, G. Subaxolemmal cytoskeleton in squid giant axon. II. Morphological identification of microtubule- and microfilament-associated domains of axolemma. J. Cell Biol., 102(5):1710-25, 1986.

Yang, L. J.; Zeller, C. B.; Shaper, N. L.; Kiso, M.; Hasegawa, A.; Shapiro, R. E. \& Schnaar, R. L. Gangliosides are neuronal ligands for myelinassociated glycoprotein. Proc. Natl. Acad. Sci. U. S. A., 93(2):814-8, 1996.

Zimmermann, H. \& Vogt, M. Membrane proteins of synaptic vesicles and cytoskeletal specializations at the node of Ranvier in electric ray and rat. Cell Tissue Res., 258:617-29, 1989.

Zimmermann, H. Accumulation of synaptic vesicle proteins and cytoskeletal specializations at the peripheral node of Ranvier. Microsc. Res. Tech., 34(5):462-73, 1996.

\section{Corresponding author: \\ Yan-Chao Li}

Department of Histology and Embryology

College of Basic Medical Sciences

Norman Bethune Health Science Center of Jilin University Changchun, Jilin Province, 130021,

P. R. CHINA

Email: liyanchao@jlu.edu.cn

Received: 18-06-2020

Accepted: 07-09-2020 